\title{
Challenges for Interdisciplinary Use in Forest Management Prompts of Coalition of Forest Management, Economic and Institutional Sciences: 2005, 361 pages
}

\section{Hariadi Kartodihardjo}

\author{
Department of Forest Management, Faculty of Forestry, Bogor Agricultural University, Academic Ring Road, Campus IPB \\ Dramaga, PO Box 168, Bogor 16680, Indonesia
}

*Correspondence author, email: hkartodihardjo@yahoo.com, tel:+62-811193383,fax: +62-251-8421355

Received 26 November 2013/Accepted 20 December, 2013

In general, the science of forest management provides guidance on how forest managers set the forest, so that it is ready to be sustainably managed and used. The forest setting is based on the natural properties of forest - bio- physical characteristics, social condition, financial, and economic. In forest management practice, the quite broad science coverage is not fully used (Kartodihardjo 2013). Regulations regarding forest management are determined more only by the forestry physical property basis, as they are contained in the various settings of the silviculture system, forest inventory, as well as forest harvesting, either in natural forest or plantation forest (Kartodihardjo et al. 2006). This practice leds science of forest management become a kind of discourse which does not have a strong relationship with other disciplines such as institutional science and political science.

\section{The science usage and policy issues}

It is not surprised if there are some people who say that the science of forest management is neutral, like a tree that "grows itself" in line with the natural laws. The context means that the running of natural law is not influenced by human being, but the existence of forest which is very wide, it is not longer be referred to as trees or set of trees that grow on their ownselves, because they are in a socio-political environment. The expansion of science based on natural laws is not longer enough to explain the issue of forest and forestry as a broader one. The discourse above does not only affect the way of individual thinking, but also produces new individuals who have a strong desire to do series of efforts that they believe as the appropriate step (Foucault 1980). Technical issues relating forest management barriers as a discourse of policy-makers have produced a very strong policy maker generation who is obsessed to solve the technical problems and is not pay attention to other matters which would be a series of primary or root cause of the problem. The strength also occurs as a result of the selection process for knowledge and information. They will marginalize the knowledge and information which are supposed not to support their discourse (Kartodihardjo et al 2013). The marginalization process of knowledge and specific information carried by the administrator policy makers are part of the process of building a discourse to suit their interests (Foucault 1980).

Although the study development of institutional and political approaches to solve the issues of forests and forestry has been done, but it has not often been really found the discourse coalition between administrators of government policy makers and the reformers who are generally outside the government, and among the researchers in both research institutions and colleges. This situation shows that the problems encountered during this time, in fact, are not due to the lack of the knowledge and information required to perform the policy reform, but due to the weakness of way of thinking and logical framework, due to the lack of collaboration between disciplines, that enables the knowledge and information be adopted as a basis for policy reform and practices in the field (Lackey 2007).

Furthermore, the problem will be more difficult when it is known that the administrators as policy makers even forget behavior characteristics and decision making done commonly by companies and society, which are very much influenced by rational choice as well as markets in daily decision making. They are generally regarded as passive actors who should obey to the technical regulations of forest management, and if they do not conduct the regulations, they will be penalized. In other words, the approach taken is legal approach and the meaning of text of the rules is the key. This approach also causes a lot of rules, because the rules are essentially a technical manual to do something, otherwise they are not restrictions and encouragement that makes the behavior lead to forest management objectives. If this rule is not running, then the content of the rules is changed or new rules are created without carefully understanding the causes.

\section{Deepening understanding}

Book entitled: Institutions, Sustainability, and Natural Resources: Institutions for Sustainable Forest Management by Shashi Kant and R. Albert Berry as the Editor which was published in 2005 by Springer-Netherland, with 361 pages, reviews in general on how the perspective of institutions applied for the review and explanation of the efforts to achieve sustainable forest management. Associated with the above issues, the book which consists of five sections and fifteen titles, clearly communicates the weaknesses of the study approach of sustainable forest management done during this time. Because of that point, this book will be an inspiration even a challenge not to use the theories of economic forest management and forestry which are generally used today, regardless of the simplification done and the fulfillment of assumptions used. 
In this book, the perspective of the institution theory associated with sustainable forest management efforts, tenure issues, forest ecosystem assessment, determination of the organization's external policy influence, and the influence of the market, invites readers to explore the nature and situation of the forest - especially the natural forest which is deeply made as an object of management. Basically, institutional perspective will finally ask the limited scope considered and the failure of the assumption realization used in the forest management approach and economic considerations (Kant \& Berry 2005). This failure in Indonesia has been demonstrated by no operation of half or more business enterprises of natural forests. In 1992, the number of natural forest business was 580 companies with total area of 61.38 million hectares, but in November 2013, the number of remaining business was 272 companies with total area 22.8 million hectares (Ditjen BUK 2013).

The characteristic of natural forest can not be replaced only by the type of dominant commodity and known the attributes of its growth as well as price, to interpret how the amount of production and the maximum cost eligibly spent (Kant \& Berry 2005). Forest conservation can not be interpreted merely to wood type circle, growth, prices and such of costs. In this case, the position of the forest as a stock of growing commodity are actually in the wider arena. Characteristics of forest with a wide range of benefits should be treated on a vast scale, so that the rights and obligations of natural forests is also imposed on the arena that goes beyond the physical boundaries of the forest. It means that institutions in forest management have scope to consider the condition and role of the public, besides their managers.

Natural forest production companies which tend to cut more trees than the necessary, people who tend to loot the forest, the rules which tend to be violated, the service bureaucracy which tends to be inefficient and corrupted, lack of capacity or lack of forest management at the site level should be a concern in sustainable forest management. When all of them become attention and resources used only from the forest, it appears that optimality theory like the optimal production, optimal rotation, the optimal profit is not appropriate to be used as a basis for sustainable forest management (Luckert 2005, in Kant \& Berry 2005). Optimality theory applied in forest management is based on a simplification of forests into timber or certain commodities within the framework of private decisions or managers (private choice), while the arena for sustainable forest management more requires decisions in consideration of the public choice.

The public-private issues became a social phenomenon (Olson 1965), in the sense that if the private decisions are made by maximizing private satisfaction or profit, the interest of the people (public) usually will be harmed. This means that forest managers who act individually are not independent or affect other party interest. In concession of production natural forest production, it means that if the company did over cutting to maximize profits, the stocks of production natural forest - which is ideally maintained by the public interest, will be reduced more quickly so it will not be able to restore the natural forest stands. Issues like this in institution theory can also be explored through the theory of contracts (contractual theory), in which the case of contract between the government and the natural forest entrepreneurs, based on the data above, has been proven to fail (contractual failure). Such failure can be caused by two causes, namely the emergence of an uncertain situation over the ongoing contract and the difficulty or the high cost to measure the performance of the contract (complex task) which raises the very high monitoring cost. This uncertainty is often caused by information on unbalanced forest conditions (asymmetric information) between the government and private companies. Efforts to overcome this phenomenon can be performed with barrier institutions (counteracting institutions) (Akerlof's, 1970 in Yustika 2012), for example in the form of warranty or the performance bonds.

Insurance fund in the form of contract is the compensation of public liability if the forest managers individually deny the contract. In Law No. 41/1999 on Forestry, the performance bond application becomes one of instrument that can be applied. The importance of the performance bonds - which until now, it is not used in the form of forest management policies to address the problem of the failure of a contract between the government and natural forest entrepreneurs. Incompleteness of information on forest potential owned by government and the high transaction costs of enforcing the contract can be conceptually addressed through the performance bonds.

In addition to the institutional approach used in solving problems of forest management, this book also reviews some principles of conservation economic of sustainable forest management that needs to be emphasized such as the principle of existence, the principle of relativity, as well as the principle of complementarity. With these principles, basically, there is no law or specific norm that can be applied in general even the certain norms should be violated. For example, in the principle of existence, the arrangement of forest management with the same results every year in order to be fulfilled the sustainable yield between generations, then such arrangement should exist, and its existence becomes mandatory. Statement of Stigler and Becker (1997) quoted from Luckert: "de Gustibus non est Disputandum" means that taste can not be blamed. The taste is the taste and it can not be justified or blamed. The taste itself should remain.

With the principle of relativity, for example, it is emphasized that the concept of optimal solution is not absolute. But here, it does not only emphasize the absolute difference and relativity in any solution, but the condition itself is relatively consistent with the behavior of the specific goals and personal interests to achieve forest sustainability (Khan 2003, in Kant \& Berry 2005). Public forests which are cut down based on household needs are relative, depending on the needs of the household. In this case, the interests of the household become a part of the existence of forest which must be considered.

While, in complementary principle, human basic behavior can not be simply regarded as "homo economicus", but the nature of selfishness of human is also accompanied by the nature of helping others, the nature of the benefit or profit maximization is also accompanied by the nature 
growing from moral values that will take benefit or advantage, the nature of high need of the forest can also be entertained by the nature of low need of the forest (Khan 2003, in Kant \& Berry 2005). Such conditions require institusion that enables the use of rules both formal and informal rules in the forest management and both of their existence and function are well maintained. It must be admitted that in the real world, the informal rules are untouched at all. Even as if there is an assumption that the legal approach is the only effective force power to control the behavior of private companies and community, and in fact this assumption has no been proved.

\section{End Notes}

The book under review is expected to be one of the cornerstone of thinkers, researchers and policy makers to pay consistently attention in fulfilling of the basic assumptions on any theory or approach of sustainable forest management used. Besides that, what is emphasized in almost the entire contents of this book, is the breadth of coverage of the phenomenon, conditions or issues that should be considered in the forest management. So that is why, the forest management science, economics, and socio-political institutions can no longer be separated in order to be able to capture the complexity of the forest management phenomenon, which is not only in the forest but also in the outside. This suggestion has actually been delivered as well by Sfeir-Younis (1991), that the way of thinking of forest management which focuses only on single forest environment is called "the forest first" and its extension is the "forest second". Ironically, the way of thinking of forest management in Indonesia is still relatively the forest first (Khan 2011).

In Indonesia, the challenge of consolidating varied sciences is extremely hard due to the forest first approach tends to be maintained by thinkers, researchers and policy makers in general. In practice, the science of forest management is developed into some technical implementations and utilizations of forest management reinforced by legal approach on the ground. Human behavioral traits and forest resources characteristics and diverse system of public values - which can be captured by the social, political, economic and institutional sciences, have not become the basic consideration in the implementation and utilization of forest management. Although the consequences of forest management failure has obviously occurred.

Therefore, despite facing severe challenges, the advice of Jarot Kintz at the beginning of this paper becomes relevant.
Short life and even long life may not be useful if they are not able to make more meaningful changes.

\section{Acknowledgements}

I would like to thank to my friends: Sudarsono Soedomo, Bramasto Nugroho and Aziz Khan, who have provided valuable input on the first draft of this paper.

\section{References}

[Ditjen BUK] Direktorat Jenderal Bina Usaha Kehutanan, 2013. Statistik Pengusahaan Hutan Indonesia. Jakarta: Kementerian Kehutanan.

Foucault M. 1980. Power/Knowledge, Selected Interviews and Other Writtings 1972-1977. New York: Pantheon.

Kant S, Berry RA. 2005. Institutions, Sustainability, and Natural Resources: Institutions for Sustainable forest Management. Netherland: Springer.

Kartodihardjo H, Didik S, Bramasto N, Ahmad D. 2013. Development of small holder plantation Forests: an analysis from policy process perspective. Jurnal Manajemen Hutan Tropika 19 (2): 111-118. http://dx.doi.org/10.7226/jtfm.19.2.111.

Kartodihardjo, H, Suparji, Beni FS, Saleh MB. 2006. Refleksi Kerangka Pikir Rimbawan: Menguak Masalah Institusi dan Politik Pengelolaan Sumberdaya Hutan. Bogor: Himpunan Alumni Fakultas Kehutanan.

Khan A. 2011. Mindset behind Indonesian forest business policy: a discourse analysis [Dissertation]. Bogor: Graduate School of Bogor Agricultural University.

Lackey R T. 2007. Science, scientists, and policy advocacy. Conservation Biology 21(1): 12 -17. http://dx.doi.org/ 10.1111/j.1523-1739.2006.00639.x.

Olson M. 1965. The Logic of Collective Action: Public Goods and the Teory of Groups. Chambridge: Harvard University Press.

Sfeir-Younis A. 1991. The Economics of Sustainability in Forestry Development. In: Proceeding 2 Discussion Area Sector A-B; Paris.

Yustika AE. Ekologi Kelembagaan: Paradigma, Teori dan Kebijakan. 